\title{
ANALISIS KESULITAN PELAKSANAAN PENILAIAN AUTENTIK DALAM PEMBELAJARAN BIOLOGI PADA KURIKULUM 2013 DI SMA NEGERI KOTA BINJAI
}

\author{
Nurlian Augustin Ningrum , Ashar Hasirin \\ Program Studi Pendidikan Biologi, FMIPA, Universitas Negeri Medan, \\ Jl. Willem Iskandar Psr. V Medan Estate Fax. (061) 614002-613319, Medan, Indonesia, 20221 \\ Email : nurlianaugustin.ningrum@gmail.com
}

\section{ABSTRAK}

Penelitian ini bertujuan untuk mengetahui kesulitan pelaksanaan penilaian autentik pada kurikulum 2013 yang dialami oleh guru biologi di SMA negeri di Kota Binjai.Penelitian ini bersifat deskriptif dengan analisis secara kuantitatif dan kualitatif. Sampel dalam penelitian ini adalah guru biologi yang berjumlah 18 orang yang diambil dengan menggunakan teknik purposive sampling. Teknik pengumpulan data yang digunakan secara triangulasi yaitu dengan pengisian anglet, wawancara, dokumentasi dan observasi langsung. Hasil penelitian menunjukkan bahwa sebagian guru biologi SMA Negeri di Kota Binjai mengalami kendala saat melaksanakan penilaian autentik. Kendala yang dihadapi oleh guru biologi antara lain kesulitan dalam pembuatan instrumen, kesulitan dalam pengisisan format penilaian, kesulitan dalam menilai sikap siswa secara objektif. Tedapat beberapa faktor penyebab guru mengalami kendala saat melaksanakan penilaian autentik yaitu jumlah murid yang tidak ideal, kurangnya pemahaman mengenai tata cara penilaian autentik, pelatihan dan sosialisasi penilaian autentik belum maksimal, sarana dan prasarana sekolah yang kurang mendukung. Tingkat kesulitan yang dihadapi oleh guru dalam pelaksanaan penilaian autentik tergolong cukup sulit dengan nilai 61,01.

Kata kunci : kendala guru, penilaian autentik, pembelajaran biologi.

\section{ABSTRACT}

This study aims to determine the difficulties of authentic assessment experienced by biology teachers in public high schools in the city of Binjai. This research is descriptive with quantitative and qualitative analysis. The sample in this research is 18 biology teacher taken by using purposive sampling technique. Data collection techniques are by filling in questionnaires, interviews, documentation and direct observation. The results showed that some of the biology teachers of SMA Negeri in Binjai City experienced obstacles while carrying out authentic assessment. Constraints faced by biology teachers include difficulties in instrument making, difficulties in filling out the assessment format, difficulty in assessing students' attitudes objectively. There are several factors that cause teachers to experience constraints when carrying out authentic assessment that is the number of students who are not ideal, lack of understanding of authentic assessment procedures, training and socialization of authentic assessment has not been maximal, facilities and infrastructure of schools that are less supportive. The difficulty level faced by teachers in the implementation of authentic assessment is quite difficult with the value of 61.01.

Keywords: teacher constraints, authentic assessment, biology learning. 
Halaman : 020 - 027

\section{PENDAHULUAN}

Kemajuan dunia pendidikan memberikan pengaruh positif dalam kemajuan suatu negara. Tujuan Pendidikan Nasional adalah mencerdaskan kehidupan bangsa dan mengembangkan bangsa Indonesia seutuhnya, yaitu manusia yang beriman dan bertakwa terhadap Tuhan Yang Maha Esa dan berbudi pekerti luhur, memiliki pengetahuan dan keterampilan, kesehatan jasmani dan rohani, kepribadian yang mantap dan mandiri serta rasa tanggung jawab kemasyarakatan dan kebangsaan. Hal ini tertuang dalam Undang-undang Nomor 20 tahun 2003 pasal 3 tentang sistem Pendidikan Nasional. Untuk mewujudkan tujuan pendidikan tersebut negara harus memiliki kualitas pendidikan yang bagus. Kualitas suatu negara sangat dipengaruhi oleh sistem di negara itu sediri. Salah satu komponen penting sistem pendidikan adalah Kurikulum.

Pada bulan Juli 2013 Kurikulum 2013 telah diterapkan di beberapa sekolah rujukan. Kurikulum 2013 ini diberlakukan secara bertahap mulai Tahun Pembelajaran 2013/2014. Ditinjau dari perubahan yang terjadi bila dibandingkan dengan Kurikulum Tingkat Satuan Pendidikan (KTSP) yang tuliskan oleh Maisyaroh, dkk (2014) maka di dalam Kurikulum 2013 lingkup standar nasional pendidikan pada standar kompetensi lulusan, standar isi, standar proses dan standar penilaian menjadi perhatian utama dalam perubahan kurikulum tersebut

Pada Kurikulum 2013 penilaian autentik menjadi salah satu karakteristik kurikulum ini. Permendikbud 66 dan 81 tahun 2013 menjelaskan bahwa penilaian autentik merupakan penilaian yang dilakukan secara komprehensif untuk menilai mulai dari masukan (input), proses, dan keluaran (output) pembelajaran, yang meliputi ranah sikap, pengetahuan, dan keterampilan. Penilaian autentik menilai kesiapan peserta didik, serta proses dan hasil belajar secara utuh. Keterpaduan penilaian ketiga komponen (input - proses output) tersebut akan menggambarkan kapasitas, gaya, dan hasil belajar peserta didik, bahkan mampu menghasilkan dampak instruksional (instructional effects) dan dampak pengiring (nurturant effects) dari pembelajaran.
Permasalahan berkaitan dengan penilaian autentik adalah sosialisasi. Menurut pengakuan guru, sosialisasi Kurikulum 2013 belum berjalan dengan sempurna terutama dalam materi penilaian. Sosialisasi mengenai penilaian autentik dianggap hanya memberikan garis besarnya saja, sehingga informasi yang didapatkan saat pelatihan tidak membuat guru mampu melaksanakan dengan baik penilaian yang dituntut dalam Kurikulum 2013. Hal ini dibenarkan oleh Ketua FSGI, Retno Listyarti dalam Ahmad (2014) mengutarakan bahwa 52 jam pelatihan tidak memadai untuk menyiapkan guru menerapkan kurikulum baru. Menurutnya, sulit untuk mengajarkan dan memaksa guru menerapkan kurikulum baru. Banyak pengamat pendidikan lainnya juga tidak setuju dengan jam pelatihan guru yang dianggap cukup singkat. Hal ini juga diperkuat oleh Alawiyah (2014) yang mengatakan masih banyak guru yang telah diberikan pelatihan belum memahami dalam mengimplementasikan kurikulum ini. Hal ini dikarenakan beberapa kekurangan dalam proses pelatihan antara lain dari sisi waktu pelatihan yang terlalu singkat, metode pelatihannya yang lebih banyak difokuskan pada ceramah, teori, dan kompetensi instruktur itu sendiri.

Guru juga mengeluhkan dengan banyaknya jumlah siswa yang ada dikelas sehingga proses penilaian tidak berjalan dengan objektif. Banyaknya jumlah siswa dalam kelas yang efektif adalah 22-26 orang dengan 1 orang guru, dengan rasio 24 : 1 namun kenyataannya di SMA Negeri di Kota Binjai dalam satu kelas terdiri dari 37-43 orang siswa. Dan juga sebagian besar guru belum memahami dengan benar mengenai penilaian autentik. Penilaian autentik mengharuskan guru untuk mengamati dan memperhatikan siswa secara keseluruhan $\mathrm{Hal}$ ini sejalan dengan penelitian Maisyaroh, dkk (2014) bahwa guru merasa kesulitan melakukan penilaian proses karena jumlah siswa yang banyak; guru belum memahami penilaian otentik; guru merasa kesulitan dalam menyusun rubrik yang sesuai dengan kompetensi dasar.

Permasalahan lain pada saat pembelajaran biologi adalah dengan banyaknya instrumen penilaian yang dilakukan. Hal ini 
dibenarkan oleh Responden, guru biologi SMA Negeri 2 Binjai mengungkapkan bahwa dalam menilai seorang siswa dalam penilaian autentik ini guru harus membuat instrumen penilaian dari penilain sikap, penilaian kognitif dan penilaian psikomotorik sebagai bukti ketuntasan hasil belajar siswa tersebut. Hal ini juga dibenarkan oleh penelitian yang dilakukan Ruslan et all (2016) yaitu permasalahan yang dialami guru dalam penilaian kurikulum 2013 adalah banyaknya jenis penilaian membuat guru kurang maksimal dalam melakukan penilaian terhadap proses pembelajaran siswa. Guru menganggap penilaian autentik ini rumit dan sulit untuk dilakukan. Karena proses penilaiannya dilakukan secara bersamaan dengan proses belajar.

Dari masalah-masalah tersebut survey menunjukkan bahwa $87 \%$ guru mengalami kesulitan dalam memahami cara penilaian, 70\% kesulitan dalam pembuatan instrumen observasi, $66 \%$ kesulitan dalam memahami model-model pembelajaran, dan $79 \%$ mengalami kesulitan membuat instrumen penilaian (Rohmawati, 2013). Hal mengindikasikan masih terdapat kendala yang terjadi dilapangan dan juga masih banyak guru mengalami kesulitan dalam pelaksanaan penilaian autentik.

Penelitian tentang kendala pelaksanaan penilaian autentik pada kurikulum 2013 sudah pernah dilakukan oleh Ruslan et all (2016). Pada penelitian tersebut guru-guru masih mengalami kendala dalam menerapkan penilaian autentik, diantaranya Kendala guru dalam menerapkan penilaian autentik di SD Kabupaten Pidie adalah penyusunan soal yang banyak, format yang terlalu rumit membuat guru kerepotan dalam melakukan penilaian kepada setiap peserta didik. Selain itu juga terdapat kendala lain yakni waktu untuk menyusun dan melaksanakan penilaian autentik. Dalam penelitian Maisyaroh et all (2014) Guru menghadapi masalah dalam pencapaian standar penilaian, yaitu: guru merasa kesulitan membuat instrumen penilaian baik tes maupun non-tes, terutama dalam mengukur ranah sikap; guru merasa kesulitan dalam mengisi format penilaian terutama rekapitulasi nilai menjadi deskriptif; guru merasa kesulitan melakukan penilaian proses karena jumlah siswa yang banyak; guru belum memahami penilaian otentik; guru merasa kesulitan dalam menyusun rubrik

Penelitian ini dilakukan untuk menguak kendala-kendala yang dihadapi guru saat melaksanakan penilaian autentik, mengingat implementasi penilaian autentik yang masih belum maksimal. Maka penulis tertarik melakukan penelitian yang tentang "Analisis Kesulitan Pelaksanaan Penilaian Autentik dalam Pembelajaran Biologi pada Kurikulum 2013 di SMA Negeri Kota Binjai Tahun Ajaran 2016/2017."

\section{METODE PENELITIAN}

Penelitian ini dilaksanakan di SMA Negeri 2 Binjai, SMA Negeri 5 Binjai, dan SMA Negeri 7 Binjai pada bulan Januari - Juni 2017. Populasi dalam penelitian ini adalah seluruh guru biologi di SMA negeri di Kota binjai. Sampel dalam penelitian ini ditentukan dengan teknik purposive samping yaitu berjumlah 18 guru biologi yang sudah melaksanakan Kurikulum 2013 selama 3 tahun pembelajaran.

Penelitian ini merupakan penelitian gabungan kuantitatif dan kualitatif. Penelitian ini bersifat deskriptif. Teknik pengumpulan data yang digunakan secara triangulasi yaitu dengan pengisian angket, wawancara, dokumentasi dan observasi langsung. Analisis data wawancara dan dokumentasi dilakukan dengan cara analisis kualitatif yaitu : reduksi, penyajian data, penarikan kesimpulan. Sedangkan data angket dianalisis dengan rumus :

$$
\mathrm{P}=\frac{\text { Jumlah skor diperoleh }}{\text { jumlah skor ideal }} x 100
$$

\section{HASIL PENELITIAN}

Penelitian ini dilaksanakan di tiga SMA Negeri di Kota Binjai. Data yang diperoleh dari angket yaitu data kendala pada pelaksanaan penilaian autentik oleh guru biologi. Anget yang digunakan bersifat tertutup. 
Halaman : 020 - 027

Tabel 1. Tingkat Kesulitan Guru dalam Pelaksanaan Penilaian Autentik dalam Pembelajaran Biologi pada Kurikulum 2013 di Ketiga SMA N di Binjai

\begin{tabular}{|c|c|c|c|c|}
\hline \multirow{2}{*}{ No } & \multirow{2}{*}{ Nama Sekolah } & \multicolumn{3}{|c|}{ Kendala Pelaksanaan Penilaian autentik } \\
\hline & & Skor & Nilai & Interpretasi \\
\hline 1. & SMA N 2 Binjai & 787 & 61,83 & Cukup Sulit \\
\hline 2. & SMA N 5 Binjai & 634 & 56,63 & Cukup Sulit \\
\hline 3. & SMA N 7 Binjai & 310 & 64,58 & Cukup Sulit \\
\hline \multicolumn{3}{|c|}{ Rata-rata } & 61,01 & Cukup Sulit \\
\hline
\end{tabular}

Data yang diperoleh mengenai Tingkat kesulitan pelaksanaan penilaian autentik dalam pembelajaran biologi rata-rata sekolah memperoleh nilai 61,01 yang tergolong cukup sulit sehingga menyebabkan terjadinya kendala. SMA Negeri 7 merupakan sekolah yang memiliki nilai paling tinggi yaitu 64,58 .

Dalam angket kendala pelaksanaan penilaian autentik ini terdiri dari beberapa indikator diantaranya adalah pelatihan kurikulum 2013, sarana dan prasarana sekolah, konsep penilaian autentik, kendala dalam penilaian afektif, kendala dalam penilaian psikomotor dan kendala dalam penilaian kognitif dan tanggapan responden. Hasil yang diperole terliha pada tabel berikut

Tabel 2. Penyebaran Nilai Pada Setiap Indikator Angket

\begin{tabular}{llcccc}
\hline \multirow{2}{*}{ No } & \multicolumn{1}{c}{ Pernyataan } & \multicolumn{3}{c}{ Nilai } & \multirow{2}{*}{ Rata-rata } \\
\cline { 3 - 5 } & & SMAN 2 & SMAN 5 & SMAN 7 & \\
\hline 1. & Pelatihan Kurikulum 2013 & 70,31 & 55,35 & 58,33 & 61,33 \\
2. & Sarana dan Prasarana sekolah & 60,93 & 51,78 & 54,16 & 55,62 \\
3. & Konsep penilaian autentik & 55,46 & 47,25 & 58,33 & 53,68 \\
4. & Kendala dalam penilaian ranah afektif. & 69,44 & 60,48 & 74,99 & 68.30 \\
5. & Kendala dalam penilaian ranah psikomotor & 56,94 & 53,56 & 56,48 & 55.66 \\
6. & Kendala dalam penilaian ranah kognitif & 61,87 & 62,49 & 71,66 & 65.34 \\
7. & Tanggapan pribadi responden & 54,68 & 51,78 & 64,58 & 57,01 \\
\hline
\end{tabular}

Berdasarkan hasil yang diperoleh dari pengisian angket pada indikator pelatihan kurikulum 2013 di tiga SMA Negeri di Kota Binjai tergolong cukup sulit yang dengan Nilai 61,33. Pada indikator aspek pernyataan mengenai sarana dan prasarana sekolah di ketiga SMA Negeri di Kota Binjai tergolong cukup sulit, namun tidak menyebabkan terjadinya kendala yang berarti hal ini di dapat dari nilai angket sebesar 55,62. Pada indikator konsep penilaian autentik di tiga SMA Negeri di Kota Binjai memperoleh nilai 53,68. Pada indikator pernyataan kendala dalam penilaian ranah afektif tergolong cukup sulit dan menyebabkan terjadinya kendala dan memiliki nilai tertinggi sebesar 68,30. Pada indikator pernyataan kendala dalam penilaian ranah psikomotor tergolong cukup sulit namun tidak mengalami kendala yang berarti dan memiliki nilai sebesar 55,66. Pada indikator pernyataan kendala dalam penilaian ranah kognitif tergolong cukup sulit dengan nilai sebesar 65.34.

\section{PEMBAHASAN}

Pada Tahun ajaran 2013/2014 ada tiga SMA Negeri di Kota Binjai yang menjadi sekolah rujukan untuk penerapan Kurikulum 2013, yaitu SMAN 2 Binjai, SMAN 5 Binjai dan SMAN 7 Binjai. Pada kurikulum 2013 ini salah satu ciri khas nya adalah penilaian autentik, guru diminta untuk melaksanakan penilaian autentik dalam pembelajaran. Dari hasil penelitian yang sudah dianalisis dari angket dan juga wawancara oleh guru-guru biologi di ketiga SMA tersebut maka di dapat sebagai berikut : 
1) Kendala-kendala dalam menerapkan penilaian autentik dalam pembelajaran Biologi di SMA Negeri Kota Binjai

Dari hasil pengamatan dan wawancara yang sudah dilakukan oleh peneliti, masih terdapat beberapa guru yang belum terlalu memahami hakikat dari penilaian autentik ini, dan implementasi penilaian autentik ini belum berjalan dengan maksimal. Dalam hal lain pelatihan kurikulum 2013 memiliki peranan penting dalam keberhasilan penerapan penilaian autentik ini. Dari wawancara yang sudah dilakukan guru membenarkan bahwa pelatihan kurikulum 2013 penyebarannya tidak merata, hal ini disebabkan pemilihan kuota peserta pelatihan yang dilakukan oleh Dinas setempat.

Dalam pelatihan kurikulum 2013 guru-guru juga mengakui bahwa mereka tidak mendapatkan informasi yang cukup lengkap dan jelas mengenai penilaian autentik, informasi yang didapat hanya sekilas saja, padahal kita tahu bahwa dalam Kurikulum 2013 ini penilaian autentik ditekankan secara khusus. Meskipun demikian, Menurut Alawiyah (2014) masih banyak guru yang telah diberikan pelatihan belum memahami dalam mengimplementasikan kurikulum 2013. Hal ini dikarenakan beberapa kekurangan dalam proses pelatihan antara lain sisi waktu pelatihan yang terlalu singkat, metode pelatihannya yang lebih difokuskan pada ceramah, teori dan kompetensi instruktur itu sendiri.

Selain pelatihan kurikulum 2013, sarana dan prasana juga menjadi kunci sukses penerapan kurikulum 2013 namun dalam kenyataan nya sarana dan prasarana menjadi salah satu kendala dan hambatan dalam penerapan kurikulum 2013 di Sekolah. Keadaan Laboratorium yang kurang memadai sehingga ada beberapa praktikum yang tidak terlaksana dalam pembelajaran dikarenakan bahan dan alat yang tidak memadai, beliau juga mengatakan bahwa bukan hanya sarana dan prasarana laboratorium tetapi juga kemampuan fasilitator untuk mengoperasikan alat di laboraturium membuat beberapa alat tidak terpakai. Mulyasa (2013) mengatakan fasilitas dan sumber belajar yang memadai merupakan kunci yang menentukan keberhasilan implementasi Kurikulum 2013 sehingga kurikulum yang sudah dirancang dapat dilaksanakan secara optimal. Fasilitas dan sumber belajar yang perlu dikembangkan dalam mendukng suksesnya implementasi Kurikulum 2013 antara lain Laboratorium, perpustakaan, dan pusat sumber belajar, serta tenaga pengelola dan peningkatan kemampuan pengelolaannya.

Selain itu responden juga mengatakan bahwa penilaian autentik ini membutuhkan banyak instrumen yang berupa kertas, namun pihak sekolah tidak memberikan fasilitas tersebut. Absari et all (2015) mengatakan sarana prasarana sangat mendukung tercapainya pelaksanaan pembelajaran, terutama penilaiannya. Namun sayangnya, ketersediaan sarana prasarana ini kurang mendukung karena pemakaiannya yang dibatasi. Sarana penunjang yang ada di sekolah hanya diperuntukkan dalam pembuatan surat untuk keperluan administrasi tata usaha sekolah. Oleh karena minimnya sarana penunjang, pelaksanaan penilaian autentik terutama penilaian sikap, berjalan tidak maksimal.

Namun kendala yang paling mendasar dalam penerapan penilaian autentik ini adalah pemahaman guru itu sendiri, dari beberapa wawancara yang sudah dilakukan beberapa guru mengakui kurang memahami maksud dari penilaian autentik tersebut terlebih lagi dengan tatacara dan prosedur penilaian yang dituntut dalam penilaian autentik tersebut. $\mathrm{Hal}$ ini dipertegas dengan pernyataan Alawiyah (2014), Ruslan et all (2014) dan Sutama (2017) yang mengatakan bahwa masih banyak guru yang belum memahami sepenuhnya mengenai penilaian autenti pada kurikulum 2013 ini walaupun sudah diberikan pelatihan dan sosialisasi. Oleh karena itu alangkah baiknya apabila seandainya guru-guru yang sudah memahami penilaian autentik ini berinisiatif secara kreatif memahamkan guru-guru lain di sekolahnya, sehingga semuanya siap mendukung penerapan Kurikulum 2013.

2) Kendala dalam Pelaksanaan Penilaian Autentik

Pelaksanaan penilaian yang dilakukan oleh guru biologi SMA Negeri di Kota Binjai meliputi penilaian sikap, penilaian psikomotor dan penilaian pengetahuan. 
Halaman : 020 - 027

Pada dasarnya penilaian autentik bukanlah hal baru dalam dunia pembelajaran di Indonesia, namun masih terdapat beberapa kendala dan hambatan yang dialami oleh guru biologi SMA Negeri di Kota Binjai baik dalam menilai sikap, menilai psikomotor maupun menilai kognitif siswa tersebut sebgai berikut :

a) Kendala dalam Pelaksanaan Penilaian Sikap (Afektif)

Responden mengakui bahwa penilaian ranah sikap sulit untuk dilakukan. Hal ini dikarenakan seorang guru haruslah menilai siswa satu persatu disaat pembelajaran berlangsung, Setyowati (2014) mengatakan bahwa kendala guru saat menilai siswa melalui observasi di dalam kelas guru harus mampu untuk fokus pada proses mengajar dan menyampaikan materi sekaligus mengamati sikap siswa dalam kelas. Hal tersbut bukanlah hal yang mudah untuk ditanggung guru.

Dalam menilai ranah sikap memiliki komponen penilaian yang tidak sedikit, hal ini lah yang menyebabkan guru merasa kesulitan dalam penilaian ranah sikap. Beberapa guru berpendapat apabila indikator penilaian yang dilakukan semakin banyak maka semakin rumit pula penilaian tersebut dan hal itu membuat penilaian menjadi tidak autentik.

Banyaknya aspek penilaian yang diukur menyebabkan guru bingung dalam menentukan sikap, aspek mana yang harus didahulukan, dan bagaimana cara melaksanakannya. Kebingungan tersebut dapat menyebabkan kekeliruan dalam penerapan pelaksanaan penilaian autentik di kelas (Absari et all, 2015). Hal ini juga dibenarkan oleh Responden 9 dan 11 beliau mengatakan bahwa kendala dalam pembuatan instrumen itu adalah menentukan indikator yang akan diamati yang sesuai dengan pembelajaran terutama dalam penilaian ranah sikap dan kemudian adalah membuat rubrik penilaian yang dirasa cukup menyulitkan responden. Hal ini sejalan dengan hasil penelitian yang telah dilakukan oleh Ruslan, dkk (2016) yang mengatakan poin penilaian yang terlalu banyak sehingga menghabiskan waktu dalam memilih aspek tersebut sehingga menyebabkan pembelajaran pada hari tersebut tidak semuanya tuntas dilaksanakan. Selain itu format yang terlalu rumit membuat guru kewalahan dalam melakukan penilaian kepada setiap peserta didik.

Dalam menilai sikap siswa guru biologi SMA Negeri di Kota binjai sebagian besar guru menggunakan teknik observasi saja, hal ini dikarenakan menurut guru teknik ini dianggap lebih mudah dilakukan guru hanya dengan melakukan pengamatan tingkah laku keseharian siswa didalam kelas saja, padahal seharusnya teknik observasi ini dilakukan dengan menggunakan lembaran observasi dan juga harus benar-benar menilai sikap siswa secara keseluruhan dari awal hingga akhir kegiatan pembelajaran. Seperti yang dijelaskan oleh Absari et all (2015) bahwa beberapa guru sering melakukan kesalahan karena penilaian yang dilakukannya hanya pada saat tertentu saja sehingga informasi yang didapatkan oleh guru menjadi terbatas.

Kendala lain dalam pelaksanaan penilaian ranah sikap yaitu jumlah murid dalam satu kelas yang tidak ideal. Menjadi seorang guru harus mampu mengenal karakter yang dimiliki oleh siswanya. Mengenal karakter siswa tidaklah mudah, karena tidak semua guru dapat mengenal karakter siswa yang ada pada seluruh siswanya. Jika ingin mengetahui karakter siswanya, maka seorang guru harus terlebih dahulu mengenal siswanya. Mengetahui karakter anak merupakan hal yang harus dilakukan oleh seorang guru. Dengan mengenal karakter anak tersebut, guru dapat membimbing dan mengarahkan siswa, kegiatan pembelajaran akan berjalan dengan baik serta mendapatkan hasil yang baik pula (Hasanah, 2014).

b) Kendala dalam Pelaksanaan Penilaian Psikomotor

Kendala yang dihadapi guru biologi di SMA Negeri kota Binjai tidak hanya pada aspek sikap saja. Pada sapek psikomotor guru kerap mengalami kendala seperti jumlah siswa yang tidak ideal, sarana dan prasarana labratorium, kesiapan siswa saat memasuki Laboratorium dan pengelolaan waktu. Dalam penilaian psikomotor, guru biologi SMA Negeri di Kota Binjai sudah menerapkan beberapa teknik penilaian seperti penilaian unjuk kerja, proyek dan protofolio. 
Penilaian ranah psikomotor ini tak terlepas dari kegiatan pembelajaran di Laboratorium, sebagian besar guru mengambil nilai psikomotor siswa saat sedang pembelajaran di Laboratorium. Guru mengeluhkan bahwasannya sarana dan prasarana di Laboratorium belum mendukung guru dalam melakukan penilaian, hal ini dikarenakan ada beberapa bahan dan alat yang tidak memadai untuk digunakan guru dan siswa saat memasuki Laboratorium. Mulyasa (2013) mengatakan fasilitas dan sumber belajar merupakan kunci yang menentukan keberhasilan implementasi Kurikulum 2013.

Selain dalam hal sarana dan prasarana guru juga mengalami kendala dalam penilaian proyek, hal ini dikarenakan penilaian proyek membutuhkan waktu yang cukup lama dan juga pengerjaannya tidak terpantau oleh guru sehingga dapat dengan mudah terjadi manipulasi data yang diperoleh siswa tersebut. Retnawati (2016) mengemukakan bahwa untuk menilai ketrampilan siswa, guru juga mengalami kendala terkait penyusunan indikator penilaian yang tepat karena kurangnya pemahaman guru terait konsep penilaian ketrampilan sesuai dengan penilaian autentik.

Selain itu waktu yang dibutuhkan untuk mencapai pembelajaran dan penilaian dalam penilaian autentik tidak lah mencukupi. Hal ini juga sejalan dengan penilitian yang sudah dilakukan oleh Magfirah (2015) yang mengatakan bahwa manejemen waktu yang dilakukan guru kurang efektif, hal ini berdasarkan bahwa melakukan persiapan dan perencanaan sebelum melaksanakan suatu kegiatan untuk mencapai sebuah tujuan sangatlah penting. Persiapan ini dapat berupa membuat daftar atau rencana kegiatan dengan memperkirakan waktu pelaksanaannya, menyiapkan instrumen penilaian, menyiapkan alat dan bahan yang dapat menunjang pelaksanaan kegiatan dan sebagainya.

c) Kendala dalam Pelaksanaan Penilaian Kognitif

Dalam penilaian ranah kognitif tidak banyak guru yang mengeluhkan kendala sela pelaksanaan penilaian tersebut. Hal ini dikarenakan penilaian ranah kognitif adalah penilaian yang rutin dilakukan oleh para guru biologi. Namun bukan berarti guru tidak mengalami kendala dalam penilaian kognitif, diantaranya adalah penyusunan rubrik penskoran dan penilaian. Kesulitan yang dihadapi guru tak hanya pada rubrik penskoran tes tertulis tetapi juga tes lisan guru mengungkapkan seharusnya rubrk penskoran dilakukan untuk menilai siswa dalam tes uraian namun kenyataannya tes uraian dilakukan tanpa menggunakan rubrik penskoran yang sesuai dengan tuntukan penilaian autentik.

Selain itu pada penilaian kognitif guru juga mengalami kesulitan saat melakukan tes lisan, hal ini dikarenakan jumlah murid yang terlalu banyak sehingga tidak memungkin seorang guru untuk melakukan tes lisan yang berjalan dengan baik. Beda hal nya apabila tes lisan dilakukan pergelombang.

\section{KESIMPULAN}

Tingkat kesulitan yang dialami guru dalam pelaksanaan penilaian autentik tergolong cukup sulit dengan nilai 61,01.Guru Biologi SMA Negeri Kota Binjai mengalami kendala dalam pelaksanaan penilaian autentik yaitu pada penilaian sikap, penilaian psikomotor, penilaian kognitif. Penyebab terjadinya kendala yang dihadapi guru dalam pelaksanaan penilaian autentik yaitu : 1) Pemahaman guru terhadap tata cara dan prosedur penilaian belum maksimal, 3) kurangnya perhatian pemerintah dan kepala sekolah terhadap guru yang belum memahami penilaian autentik, 4) Sarana dan prasana sekolah yang kurang mendukung, 5) Sosialisasi penilaian autentik belum berjalan dengan maksimal, 6) Guru belum melaksanakan penilaian autentik dengan maksimal, 7) Kurangnya waktu untuk penyampaian materi dan sekaligus untuk menilai.

\section{DAFTAR PUSTAKA}

Absari, L., Sudiana, N., dan Wendra, W., (2015), Penilaian Autentik Guru Bahasa Indonesia dalam Pembelajaran Menulis Siswa Kelas VII di SMP Negeri 1 Singaraja, e-Journal Universitas Pendidikan Ganesha, 3(1) : 1-12.

Ahmad, S., (2014), Problematika Kurikulum 2013 dan Kepemimpinan Instruksional Kepala Sekolah, Jurnal Pencerahan, 8(2) : 16931775. 
Alawiyah, F., (2014), Kesiapan Guru dalam Implementasi Kurikulum 2013, Info Singkat Kesejahteraan Sosial, 6(15) : 9-12.

Hasanah, N., (2014), Pentingnya Mengenal Karakteristik Siswa http://www.kompasiana.com/nidaulhasana h/pentingnya-mengenal-karakteristiksiswa 54f7779ba33311bf668b4595

Maisyaroh, Zulkarnaen, W., Setyowato, A., J., dan Mahanal, S., (2014), Masalah Guru dalam Implementasi Kurikulum 2013 dan Kerangka Model Supervisi Pengajaran, Jurnal Manajemen Pendidikan, 24 (3) : 213-220.

Maghfirah, S., (2015), Kendala Guru Pada Penerapan Penilaian Autentik Dalam Pembelajaran Eksponen Dan Logaritma Di Kelas X Sma Negeri 1 Banda Aceh Tahun Pembelajaran 2014/2015, Universitas Syiah Kuala, Banda Aceh.

Mulyasa, E., (2013), Pengembangan dan Implementasi Kurikulum 2013, Remaja Rosda Karya, Bandung.

Retnawati, Heri, dkk (2016), Vocational High School Teachers Difficulties in Implementing The Assesment in Curriculum 2013 in Yogyakarta Province of Indonesia, International Journal of Instruction, 9 (1) : 114

Rohmawati, (2013), Kurikulum 201387 Persen Guru Kesulitan Cara Penilaian, https://unnes.ac.id/berita/87-persen-gurukesulitan-soal-penilaian-kurikulum-2013/ (Diakses : 13 Desember 2016).

Ruslan, Fuziyah, T., dan Alawiyah, T., (2016), Kendala Guru dalam Menerapkan Penilaian Autentik di SD Kabupaten Pidie, Jurnal IImiah Mahasiswa Pendidikan Guru Sekolah Dasar, 1(1) : 147-157.

Sutama, Sandy, G., A., dan Fuadi, D., (2017), Pengelolaan Penilaian Autentik Kurikulum 2013 Mata Pelajaran Matematika di SMA, Jurnal Manajemen Pendidikan, 12(1) : 105114. 